\title{
Unusual case of hemiarhinia
}

\author{
Gunjan Gupta, Vijay Kumar Diwana, Kunal Mahajan, Rajesh Chauhan
}

Indira Gandhi Medical College, Shimla, Himachal Pradesh, India

\section{Correspondence to} Dr Kunal Mahajan, kunalmahajan442@gmail.com

Accepted 21 February 2017
CrossMark

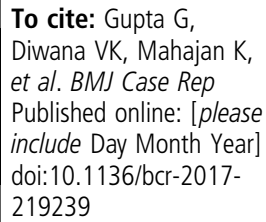

\section{DESCRIPTION}

A boy aged 9 years presented to our clinic with the absence of the left side of the nose (figures 1 and 2). There was no symptom of difficulty in nasal breathing and parents were only concerned regarding facial disfigurement. The boy was born at full term via a normal vaginal delivery and the antenatal period was uneventful. There was neither any history of consanguinity nor similar symptoms in the family. On examination, the lower two-third of the left side of the nose was absent with marked deviation of the nasal septum towards the right. There was gaze nystagmus with left esotropia on ophthalmological examination. High-resolution CT showed bilaterally symmetrical nasal bones with rudimentary right nasal cavity. There was marked deviation of the nasal septum towards the right with hypoplastic left-sided paranasal sinuses (figure 3). Extensive screening for congenital malformations in other organ systems including cardiovascular system was negative. This unusual contralateral sinus and facial anomaly is a matter of clinical curiosity and such a case has seldom been reported before.

Hemiarhinia, also known as heminasal aplasia or unilateral aplasia, is a rare malformation that

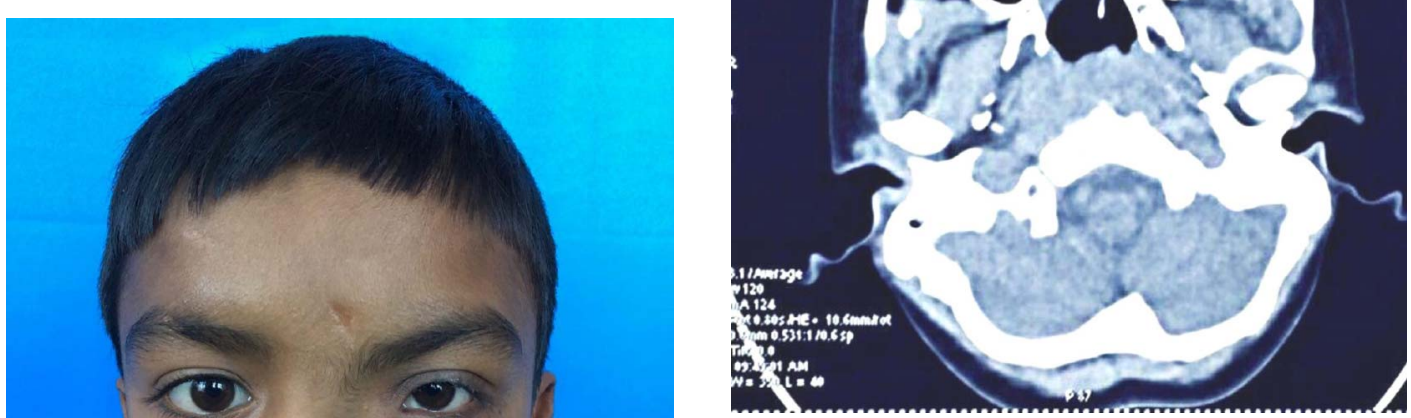

Figure 3 Axial view high-resolution CT showing rudimentary right nasal cavity (yellow arrow) with hypoplastic left maxillary sinus (black arrow).

includes unilateral absence of the nasal structures, including external nose and internal nasal cavity. ${ }^{1}$ In non-syndromal cases, ipsilateral-associated anomalies may include abnormalities of the facial bones, absent or hypoplastic sinuses. ${ }^{2}$ Nasal reconstruction was deferred until preschool age, when development of facial structures is nearly complete. A multidisciplinary approach including rhinologists, maxillofacial surgeons, paediatricans and plastic surgeons is recommended. 


\section{Learning points}

- Hemiarhinia is a rare congenital malformation of unknown aetiology. Less than 100 cases have been described in the literature so far.

- Associated anomalies include the absence of ipsilateral paranasal sinuses and ipsilateral facial malformations; however, occasionally, the contralateral side may also be affected, as in our case.

- Nasal reconstruction is deferred until preschool age when development of facial structures is nearly complete.

- Since individuals with heminasal aplasia have normal contralateral nasal structures, most patients do not have functional deficits and hence the prognosis is good.
Contributors GG and VKD made the diagnosis and performed the complete investigations and were involved in the management of the patient. KM wrote the manuscript. RC performed the literature search. GG and KM corrected the manuscript and gave conceptual advice. All authors read and approved the final version of the manuscript.

Competing interests None declared.

Patient consent Obtained.

Provenance and peer review Not commissioned; externally peer reviewed.

\section{REFERENCES}

1 Nagasao T, Nakajima T, Hikosaka M, et al. A rare case of congenital unilateral hypoplasia of nose. J Plast Reconstr Aesthet Surg 2009;62:e305.

2 Guion-Almeida ML, Machado-Paula LA, Richieri-Costa A. Newly recognized syndrome with heminasal aplasia and ocular anomalies or wider spectrum of heminasal aplasia/atypical clefting syndrome? Am J Med Genet Part A 2004;129:156.

Copyright 2017 BMJ Publishing Group. All rights reserved. For permission to reuse any of this content visit http://group.bmj.com/group/rights-licensing/permissions.

BMJ Case Report Fellows may re-use this article for personal use and teaching without any further permission.

Become a Fellow of BMJ Case Reports today and you can:

- Submit as many cases as you like

- Enjoy fast sympathetic peer review and rapid publication of accepted articles

- Access all the published articles

- Re-use any of the published material for personal use and teaching without further permission

For information on Institutional Fellowships contact consortiasales@bmjgroup.com

Visit casereports.bmj.com for more articles like this and to become a Fellow 